\title{
THE ORTHODOX UNDERSTANDING OF WAR AND VIOLENCE
}

\author{
UDC 327.88:271.2
}

\section{Danijela Milošević}

\author{
National Security Academy, Belgrade, Republic of Serbia
}

\begin{abstract}
The question of the influence of religion, i.e. the teachings of certain religions regarding the understanding of certain cultural, social and political phenomena, either individually or in cooperation, is of significant importance particularly when those teachings refer to the manifestations of political violence. Of fundamental importance is also a proper insight into the similarities and differences which exist in defining the authority these understandings impose, as well as the sources from which these interpretations are derived. In this paper, the author analyzes the Orthodox understanding of political violence and how it manifests itself, relying on the dogmatic teaching of the Orthodox Church whose primary sources are the Holy Bible and canonical law.
\end{abstract}

Key words: Orthodoxy, manifestation of political violence, war, violence, Church, Holy Bible.

\section{INTRODUCTION}

Religion as a significant political phenomenon, and its influence on the greater political tide, has largely been cast aside, largely thanks to a more secular view of the world within theoretical thought. However, according to the American sociologist Professor Peter Berger, "those who ignore religion in their analyses of modern events do so at their own peril" (Berger, 2008: 12).

Starting from the positions and thoughts of certain religions as presented by their leaders, we see that they all have similar characteristics. They all profess that their religious teachings point towards peace, love, tolerance, communal benefit, and in essence present themselves as the source of all things good. Historical events, however, paint a very different picture of reality. Holy wars have marked considerable periods of human civilisation throughout history, and history has shown that religion can be a factor in social disintegration as much as in social cohesion.

The teaching of the major religions regarding war and peace is just one of a number of questions concerning the study of religious politicology. It is to do with a conundrum

Received September $23^{\text {rd }}, 2017$ / Accepted November $27^{\text {th }}, 2017$

Corresponding author: Danijela Milošević, Spec. in Politics and Religion, National Security Academy, Belgrade, Serbia E-mail: milosevicdanijela10@yahoo.com 
that Professor Miroljub Jevtić, when determining a case for this new political discipline, places into a group of questions concerning "all things within the framework of religious teaching which in content and message are directly political" (Jevtić, 2009:18). It is to do with a rather significant conundrum which raises further questions. Above all, how do the positions of certain religions and their denominations differentiate, or even clash, when dealing with such important problems that humanity faces such as war and peace?

In this case, of interest is how an individual or a group that belongs to the Orthodox Church, and lives the Orthodox way of life, posits themselves in a life-or-death situation when faced with the dilemma "kill or be killed". Is the use of force against evil justifiable and, if so, does this action have a base in the Holy Bible? A more significant inquiry is to what extent religious positions are opposed regarding answers to the aforementioned questions. In this paper, the author will attempt to answer these questions by analyzing the positions rooted in the Orthodox, theological and political notions.

\section{THE PECULIARITY OF ORTHODOXY}

The Orthodox Church is Episcopal in organization. It does not have a geographical or administrative centre. It is comprised of individual churches which are financially and administratively independent. This decentralised organization does not mean that each autocephalous church has the right to arbitrarily change the Orthodox canon, dogma or liturgics. Internal questions are solved within each church in such a way as not to stray from the canonical order. "The Orthodox Church is in fact built on a spiritual completeness...; the internal uniformity of the collective Orthodox Church is comprised of unity of faith, unity of charity, unity of prayer and liturgy, unity of discipline and oneness of church hierarchy, so that the faithful and clergy of each autocephalous church can visit a neighbouring confessional (Orthodox) church and feel as if they are in their own" (Milin, 2002:39).

It should be taken into account that, when speaking of the Orthodox position, we consider all countries and regions whose primary religion is Orthodoxy - Russia, Belarus, Greece, Cyprus, Ukraine, Bulgaria, Romania, Moldova, Georgia, Armenia, Montenegro, Macedonia, Republic of Sprska, and Serbia. According to available statistics, $33.35 \%$ of the world's population identifies as Christian, of whom $4.03 \%$ are Orthodox. These statistics are taken from the CIA website, where it is also claimed that only $10-15 \%$ of the population in Russia identifies as Orthodox; taking into account this estimate from this site, we also have available the total number of people identifying as Orthodox. However, according to research conducted in 2006 in Russia by the Institute for Socio-Political Research of the Russian Scientific Academy, investigating the religiousness of the population, "Orthodoxy is the foundation for the self-identification of $65 \%$ of Russian citizens and 75\% of ethnic Russians" (Sinelina, 2010: 94).

Apart from statistics identifying the number of adherents of the Orthodox faith worldwide, the geopolitical positioning of the aforementioned countries, their surroundings and history must also be taken into account. 


\section{ON WAR AND VIOLENCE}

In the interests of a better understanding of an official stance towards war and violence, it is important to indicate the dominant theoretical notions and definitions of these ideas in political science. The most well-known definition of war is given by Carl von Clausewitz who states that "war is not merely a political act, but also a real political instrument, a continuation of political commerce, a carrying out of the same by other means". Politicologist Ljubomir Tadić defines war as "the most bitter battle between political communities" (Tadić, 1996:18).

When defining the notion of violence, Professor Simeunović asserts that "all violence uses force" (Simeunović, 2009:102), i.e. it concerns "a happening by which an act, activity, action or process begins, carries out and ends... in contrast to the will and intention of achieving interest and satisfying the need of the object of that force" (Simeunović, 2009:102). In that vein, political force can be "broadly classified as direct or indirect latent use of force in the political sphere; that is, direct or indirect latent use force against mind, body, life, will and tangible good, both real and potential, i.e. against a supposed political opponent" (Simeunović, 2009:103).

War is undoubtedly the most severe form of conflict between two opposing parties, where human nature is unmasked and people are prepared to commit unspeakable horrors. Although throughout history various peace accords have been drafted and implemented (for example, the Hague Conventions of 1899 and 1907, the 1921 Washington Naval Conference, and the 1928 Kellogg-Briand Pact where signatory parties shunned war as an option in national politics, and thereafter the League of Nations and the United Nations where the idea of peaceful coexistence was postulated but never put into effect), war has become more brutal, armament more precise, and goals and pretences much greater.

\section{PRE-CHRISTIAN VIEWS OF WAR}

Until the first half of the $4^{\text {th }}$ century, the first adherents of Christianity held the belief that war and violence were to be totally prohibited. Prayer was considered to be the only acceptable 'weapon' in the fight against an enemy. Notable Roman writers such as Tertullian, Lactantius, Origen (et al.) held the following position which was eventually absorbed by collective socio-political relations which the early Christians were surrounded by: the writers were "against Christian adherents serving in the Roman army and spilling blood, this (was) seen as un-Christian-like; it is also interpreted that the Roman army knew not of God and were sympathisers to slavery, and were therefore in no way Christian. Eschatological reasons were also put forward, that is understandings regarding the coming end of the age, the punishment and eradication of sinners, followed by the rule of the righteous, thereby every war is actually committed in vain and is unnecessary" (Marić, 1935: 17).

In 313, when the Milan Edict gave Christians the right to freely practice their faith, several changes were put into effect, which led to Christians being able to participate in wars. In time, theoretical justifications for the use of force against opposition surfaced, chiefly propagated through the teachings of Thomas Aquinas regarding "just war" (jus bellum iustum). "Righteous wars are those that seek vengeance against injustice, when one society or nation against whom a war is enacted has not sought to punish the crimes of their own people, or if they have not returned that which they have taken in an unjust 
manner" (Jovanović, 2007: 243). This concept was later misused in the quest for the justification of religious practice, notably during the Crusades which effectively negated everything that Christianity in essence stood for. In accordance with the aforementioned views, Christian thought morphed through three stages: pacifism, just war, and the Crusades.

\section{THE HOLY BIBLE - WAR - VIOLENCE}

It is not possible to speak of the Orthodox notions of war and violence unless it comes directly from its primary source: the Holy Bible and its content. To what extent these notions can survive in social relations depends on the degree of religiosity of individuals as well as collectives that nominally belong to Orthodoxy.

\subsection{Old Testament}

Theorists often differentiate between the Old and New Testaments, pointing to commandments in the Old Testament which under the law of talion speak of brutal punishments. It is said that harm should be returned with equal measure: "Show no pity: eye for an eye, tooth for a tooth..." (Deuteronomy 19:21). On the other hand, theologists hold the position that Old Testament lessons are merely preparations for the New Testament which teaches much higher concepts. "Both are laws from the same Lawgiver. That is God. Referring to people of various leadership, various character and various degrees of striving for perfection both Old and New laws are important... For those who have God's love within themselves, the law of love overwrites all other laws... for love means carrying out that law... for those who have not felt God's love within, the Old laws are valid" (Velimirović, 1996:73).

The act of killing is both prohibited and allowed, depending on the situation in which it is committed, which in no way contradicts the modern understanding of killing: in any case, the sixth commandment "Thou shalt not kill" is both clear and enduring. When it comes to war, the relationship between Jacob and Israel is important. The Lord fights for the "chosen people" in all those cases when Israel holds that vow, living according to God's commandments - "Because the Lord your God is the one who goes with you to fight for you against your enemies to save you" (Deuteronomy 20:4).

The moral codes for war are clear and precise: take due care from everything that goes against Old Testament code: "When thou goest forth into camp against thine enemies, then keep thee from every evil thing" (Deuteronomy 23: 9). Failure to abide by these commandments, as a rule, led to the outcome that Israel meets defeat and slavery. We recognize that life in peace and well-being was related to periods in which the "chosen people" lived in trusting in the Lord and divine laws, and that turning to idolatry, debauchery, adultery and deceit led to the acceptance of the customs of the people they were surrounded by, thereby rejecting the laws of God; of course punishment would follow, for as Nikolai Velimirovic states: "war is God's quickest act of retaliation for long-lasting acts of people during times of peace" (Velimirović, 1996: 149).

In the work "War and the Bible", when speaking about the causes of war, Velimirovic points out that war can only be explained with respect to the Bible: Cain shed the blood of his brother Abel, and thus war on earth began. Envy is overtaken by an internal conflict which manifests itself in the murder of a brother. As Velimirović points out, it is this fact that is the indisputable cause of all wars: "There exists an unshakable law of sin - war of 
man against man is the result of the war of man against God; war of parents against God is continued by their children who subsequently wage war against each other. The grace of the Creator alleviates the law of sin and enables the continuation of the human race on earth" (Velimirović, 1996:157). Everything is interdependent; war and the suffering it carries are given as a warning, a sign that there has been a deviation and a departure from God, a sign that Christian morality and spirit have been forgotten by those to whom the warning is issued. For this reason, the Holy Fathers emphasize above all the importance of the internal struggle that each individual must first carry with him, and that achieving inner peace is a prerequisite for good relations with the immediate and wider surrounding.

There are opinions which are not uncommon, especially among Protestants, where accounts of Israel's clashes with the wicked speak of grave things, where nobody was spared (including children). In response, Velimirović has an interesting opinion; he points out that the grace of God cannot be called into question "before one realizes all fearsome sins and the vices of the people"; therefore, Velimirović postulated the following question: "After all, who can dispute the right of the gardener to remove in his own garden one rotten vegetable and plant another better and healthier? So, who can question to the very end the depth of God's plan?" (Velimirović, 1996: 164).

\subsection{New Testament}

The New Testament presents a new and markedly different message, where the law of talion is transformed into the law of forgiveness. Jesus Christ teaches endurance and love through example. The idea of a promised land is no longer offered, to which Israel had exclusive right. Instead, everything is directed towards a higher level that the Lord offers now to all people, provided that life is lived through free will and preparation according to the commandments of God.

There is no explicit position regarding war, but it stems from Gospel teachings which refer to relations between friends, enemies and evil. During the Sermon on the Mount, Jesus Christ said: "You have heard that it was said 'eye for eye, and tooth for tooth'. But I tell you, do not resist an evil person. If anyone slaps you on the right cheek, turn to them the other cheek also" (Mattthew 5:38-39). That is not all; what follows is the teaching that raises Christian theology above other religious teachings: "But I say to you, love your enemies, bless those who curse you, do good to those who hate you, and pray for those who spitefully use you and persecute you" (Matthew 5:44).

Commandments which call for evil being countered with good, enduring physical blows and praying for your enemies point to the necessity for all individuals separately to draw closer to a greater purpose; it is asked of Christians that with every breath, action and thought they draw nearer to the Lord, supporting all things good as is directed by Scripture: "be perfect, therefore, as your heavenly Father is perfect" (Matthew 5:48). Interpreting these words in such a way as to retain the foundations of Orthodox spirituality, Justin Popović writes: "Countering evil with evil and insult with insult is much easier than countering evil with good and insult with forgiveness, for the latter requires a much greater undertaking...; a Christ-like soul is required which constantly resides in Christ the Lord..."(Popović, 2004: 216).

Of great significance regarding the message of forgiveness are the thoughts of Russian monk Ignatij Brjančaninov who calls for wisdom, for, as he says: "that same Scripture commands that we be cautious around our enemies and to not take them for their word... 'I 
am sending you out like sheep among wolves; therefore, be as shrewd as snakes and as innocent as doves' (Matthew 10:16)...; thus, the Scripture calls for caution around enemies and, where possible, wise dealings with them" (Brjančaninov, 2005:201).

In theological and political Orthodox understanding, two differing schools of thought have emerged regarding the interpretation of the aforementioned message. On the one hand, there is a call for a complete resistance to evil through pacifism, resulting from a literal acceptance of the commandment "Thou shalt not kill", which is supported by L. N. Tolstoy; however, his viewpoint among Orthodox scholars and philosophers is often seen as quasi-Christian, while Berdyaev defines this thought as abstract moralism (Spinka, 1950:153). On the other hand, a more widely represented viewpoint and supported in the writing of holy fathers is that participation in war is not prohibited, nor is the use of selfdefence against physical force, but under certain conditions:

- There needs to exist a real threat which endangers the lives of those around us and which cannot be solved peacefully

- Opposition to evil needs to be in line with the perceived threat and in accordance with Christian moral ideals.

In his book "Orthodoxy and War", Grozdić states that a call for love towards an enemy "does not mean love towards evil...; although Christ preached love towards enemies and forgiveness of sin, this love and forgiveness was to be directed towards enemies of people, whose insults we can choose to forgive or not forgive...; however, we must never show love towards enemies of God" (Grozdić, 2001:21), thus interpreting the Old Testament commandment "Love one another as you do yourself" and the commandment "Love each other as I have loved you. Greater love has no one than this: to lay down one's life for one's friends". Grozdić continues: "Concerning the Orthodox understanding of war, one cannot ignore their inner voice or the cry of an endangered society" (Grozdić, 2001:170).

From this perspective, we see that it is important to distinguish between personal enemies and God's enemies, and therefore act appropriately in a given situation. Of similar opinion is Poznanović who states: "pacifism which stems from egoism goes against Christianity, for it represents making peace with, as well as submission to, evil" (Poznanović, 2001: 57).

One example can be found in the Gospels, where the Lord reacts with force: "In the temple courts he found people selling cattle, sheep and doves, and others sitting at tables exchanging money. So he made a whip out of cords, and drove all from the temple courts, both sheep and cattle; he scattered the coins of the money changers and overturned their tables" (John 2:14-15). This is the moment that Christ confronts sacrilege in a holy place, a place of sanctuary and prayer, and there is no way that the behaviour of the people in the temple can be described other than hostile and blasphemous, behavior which completely goes against everything the Holy Bible teaches.

From this we can deduce that opposition to evil with physical force is justified in any vital situation where defending someone "close" to you against obvious danger cannot be avoided. In such cases, one may protect another even by sacrificing one's own life. However, it is important to note that the idea of someone "close" to you can be interpreted broadly: when speaking about the Good Samaritan, the Lord considers love to be the virtue above all virtues, and says that a "close" person can be anybody regardless of where they are from, for as long as they also carry love for all in their heart.

The Russian philosopher Nikolai Ilyin indignantly rejects Tolstoy's "abstract moralism". In his book "On Resistance to Evil by Force", he states that defence by force is necessary for 
as long as certain criteria are met: "the actual existence of evil and not an illusion of evil, the evil can be undoubtedly observed, love and desire are in the soul of the person resisting the evil, and finally the need for practical prevention of the evil" (Grozdić, 2001: 53).

The Orthodox view of war and the depth of Christian morality are reflected in the thoughts of His All-Holiness, the late Patriarch Pavle: "In any case, the Christian position is that war is evil; however, from that same Christian viewpoint, sanctified defensive war is permitted while a war of conquest is condemned. In a defensive war, people must remain humane and worthy to be called Christian, that is, one should not act towards an evildoer in the same manner that the evildoer would act towards them."(Dveri Srpske, 2002).

This notion has been incorporated by Orthodox communities since early times thanks to the Orthodox faith, as evidenced by a number of notable battles. The Battle of Kulikovo (1380) and the Battle of Kosovo (1389), significant battles for the Russian and Serbian people respectively, were sanctified by the Church and it was this sanctification that permitted the battles to go ahead at that time. Although their outcomes were different, they present themselves as examples of the permeation of the Orthodox and national spirit; the first battle was a deciding factor in the unification of Russians, while the second battle left a lasting legacy for the Serbian people, speaking of survival and continuance in spite of current negative outcomes which have appeared throughout history. Taking into account the current state of the Serbian province of Kosovo and Metohija, we realise that the Battle of Kosovo continues on today. This kind of perseverance and endurance brought about a confrontation with the enemy, who perceived it as negative due to the faith the Serbian people practiced; consequently, cruel acts towards Christians were seen as justifiable.

In Orthodox thought, war is undoubtedly characterized as evil, and though participation is justified only under lines of defending an existing order, even then one must not forget to act towards an enemy in a way that the faith prescribes, i.e. violence that crosses the line of necessary defence is prohibited.

\section{THE StANCE ON WAR AND MURDER IN THE ORTHODOX CANON}

Canons are written rules which in a broadly binding manner regulate and uncover the teachings of the Orthodox Church. The primary source of canonical law is the Holy Bible and holy teachings: these are comprised of the tenets of the Holy Apostles, ecumenical councils, commemorative councils and the tenets of the Holy Fathers.

Congruent with modern legislation, these laws include a distinction between intentional and unintentional murder, which lies in the intent of the perpetrator. Consequently, sanctions are determined: more stringent sanctions for intentional murder and more lenient sanctions for involuntarily murder. In the spirit of the church order, the latter implies denying Holy Communion to the perpetrator.

The most severe punishment is outlined in the 22nd rule of the Synod of Ancyra, which prescribes the lifelong denial of Holy Communion for the perpetrators of murder committed with intent: "Those who commit willful murder must for the rest of their life remain attached (to the Church) and only at the end of their lives they are welcome to completely partake in Church rituals (including Holy Communion)" (Milaš, 2004:23); an unintentional murder is punishable by seven years of denial of Holy Communion. Killing in battle is mentioned in the first canon of St. Athanasius the Great, who stated that "killing is not allowed, but killing enemies in war is both legitimate and dignified" (Milaš, 2004: 330). A 
similar position is held by St. Basil the Great who, in his $13^{\text {th }}$ canon, recommends that soldiers who kill during war should not take Holy Communion for at least three years, even though they have "unclean hands". In his $8^{\text {th }}$ canon, St. Basil the Great also explains when killing is considered intentional or unintentional; for an intentional murder, one is banned from Holy Communion for twelve years whereas a seven-year prohibition is envisaged for unintentional killing. According to the $11^{\text {th }}$ canon, these punishments may be relaxed; thus, the length of prohibition can be shortened when the person who has passed the judgment deems it to be appropriate (Milaš, 2004).

It is vital to point out that opposing evil by force is not experienced in only one way, as viewed from the perspectives of lay people and members of clergy; in particular, monasticism is a typical way of accepting suffering in whatever form it manifests itself. Furthermore, the greater the suffering and tolerance, the greater the chance to secure a place in the heavenly kingdom - that is what every Christian, particularly monks, prepare for and expect. It is also important to note that the Orthodox church canons explicitly forbid members of the clergy to participate in armed conflict. In addition, Christians who commit murder are not able to obtain the role of priesthood.

Yet, past wars of Orthodox nations have shown numerous examples of clergy participating in armed conflict in an effort to free their people. Reflecting on the earlier explored idea of personal enemies and enemies of God, this idea can help us understand what may appear to be a contradiction in itself. For example, St. Peter of Cetinje, after his numerous requests for peace to Kara Mahmud Pasha fell on deaf ears and confronted by the sight of his people suffering, decided to use force and directed his people: "for every faithful son (to) participate in the defence of our true faith and our dear liberty, to enact vengeance against the son of Muhammad for committing acts of religious destruction with weapons in his hands... to be immediately prepared" (Popović, 1996: 24).

In his work "Orthodoxy and War", Matej Arsenijević also confirms the already featured position that "the Orthodox acceptance of war is to fight a just war in a just manner, 'according to the rules' of the teachings of a Christ-loving style of warfare for which is prayed at every Liturgy, for a just cause" (Arsenijević, 2000). He also states that one cannot speak of a "holy war" in Orthodoxy, given that every armed battle supposes the killing of an enemy; therefore, this act excludes the possibility of its sacralization.

\section{CONCLUSION}

In the course of history, the understanding of the attitudes towards war and violence has changed under the influence of various socio-political relations and positions, in which Christian communities were situated at any given time. The first period of Christianity was characteristically marked by the idea of total opposition to any form of violence as a means of standing up to an enemy. Afterward, influenced by the teachings of "righteous war", this position changed under the auspices of the Catholic Church, which had utterly negative consequences. As a result, Christians of the Eastern churches suffered as well.

Regarding the Bible's attitudes towards these issues, we may observe distinctive views as given through Old and New Testament perceptions. The Old Testament message, embodied in a simple statement that the committed sin is punishable and that everything is based on the "cause-effect" relationship, was noted in the lectures of Nikolai Velimirović, where he says: "That is why when Israel (as God's earliest 'church') deviated from God 
and His law, God chose Nebuchadnezzar as His servant to punish the deviants of Israel. That is why when the Christian people in Asia and Africa, through a multitude of heretical actions, deviate from God, God chooses the Arabs as His servant to punish the Christians so they could learn their lesson. Thus, when the Christian people of the Balkans deviated from God and His law, God called upon the Turks as His servants to punish the deviants, and to punish them appropriately" (Velimirović, 2000). This "cause and effect" relationship is also featured in the New Testament period.

It is clear that throughout history the Orthodox people and the Orthodox Church have crystallized the position that the use of violence and participation in war is to be a last resort, which is to be used solely when the war is defensive in character, when it protects individuals or communities, and when the underlying values justify the use of physical force, whereby the force has to be proportional to the attack. At the same time, the attitude towards an enemy should rest on love for enemies as human beings; in particular, this means that humiliation or abuse is not allowed in war because our love towards the enemy is expressed by the way we choose to treat them.

The ethics underlying the Christian attitude towards an enemy was expressly stated by King Alexander I Karađorđević on $5^{\text {th }}$ October 1912, when he received command over the First Army: "Towards a defeated enemy, or a enemy that surrenders, you must be humane and merciful, for at that point he ceases to be your enemy but remains to be a man, who must be given humane treatment. The houses, lands and the reputation of your fallen enemy must be saved and protected, just like the houses, lands and the reputation of your fellow countrymen; for, not only is it required by humanity and by our Orthodox faith but it is also a distinctive feature that befits and defines heroes..."(Arsenijević, 2000).

Unfortunately, among adherents of the Orthodox faith there was falling out and distancing from the Christian principles which are reflected in the actions of those dissidents. Yet, the consciously committed actions of a few cannot be used to blame the entire group they belong to; in particular, these actions cannot be attributed to the Orthodox teaching. "Christianity places a responsibility on its adherents, for man is created as a free being and, in that vein, is morally responsible for his actions" (Loski, 1982:133).

Conquering evil with good is an eternal message of Orthodoxy; good is exemplified by endurance, self-control, abdication. The concept of suffering is essential to Orthodoxy and is even seen as a joyful event, for it leads to redemption of sins and becoming closer to God. Comprehending such a mystical understanding of God is a precondition for comprehending the Orthodox view of faith. According to Professor Đorđević, this approach to the understanding of the world is the reason why "Orthodoxy and the Orthodox do not have the immunity (defense mechanism) to the challenges that the contemporary West teaches them. This is again the enduring cause of the suffering of the Orthodox in the past, in the present and probably, in the future" (Đorđević, Milošević, 1994).

It is a fact that even the New Testament does not promise Christians peace; rather, in the spirit of revelation, a clear message is given that peace will not exist on this earth: "You will hear of wars and rumours of wars, but see to it that you are not alarmed. Such things must happen, but the end is still to come. Nation will rise against nation, and kingdom against kingdom. There will be famines and earthquakes in various places" (Matthew 24:67). Indeed, from today's perspective, taking into account the events that mark our present time and seeing hints of things that could happen in the future, the question arises (although the answer may already be evident): can mankind hope for everlasting peace? 
Nevertheless, although nothing suggests the possibility of achieving universal peace any time soon, especially considering the growing number of conflicts in international relations, Orthodoxy is the religion of hope, a religion whose message is communicated through one word: love. It is, therefore, the duty of all Orthodox Christians to lead a life worthy of that title, working with effort to resist evil with good wherever possible and to not endanger the lives of others around them.

\section{REFERENCES}

Arsenijević, Matej (2000), Pravoslavlje i rat, U: Jagnje Božije i Zvijer iz bezdana: Filosofija rata, Zbornik sa Drugog bogoslovsko'filozofskog simpozijuma (ur. R.M. Mladenović, Jovan Ćulibrk; Projekat Rastko: Biblioteka srpske kulture na internetu: Filosofija, elektronsko izdanje objavljeno 27. 01. 2000; https://www.rastko.rs/filosofija/ jagnje/matej_arsenijevic_c.html

Biblija, Stari i Novi zavet, prevod Đure Daničića;

Berger, P., (2008). Desekularizacija sveta, Mediteran Publishing, Novi Sad;

Brjančaninov, I.,(2005). Enciklopedija pravoslavnog duhovnog života, Finegraf, Beograd;

Grozdić, B., (2001). Pravoslavlje i rat:Prilog proučavanju shvatanja Srba o ratu, Novinsko izdavački centar VOJSKA, Beograd;

Đorđević, D., Milošević, Z., (1994). Pravoslavlje, rat,stradanje, Religija-rat-mir, JUNIR,Niš;

Jevtić, M., (1994). Konfensionalni elemenat međuetničkih sukoba u Jugoslaviji, Religija-rat-mir, JUNIR, Niš;

Jevtić, M., (2009), Politikologija religije, Centar za proučavanje religije i versku toleranciju, Beograd;

Jovanović, Miloš (2007), Doktrina pravednog rata i međunarodno pravo. U: Međunarodni problemi, Vol. LIX,

br. 2-3, Jun 2007, str. 243-265. http://www.doiserbia.nb.rs/img/doi/0025-8555/2007/0025-85550703243J.pdf

Loski, N., (1982). Ruska religijska filozofija i F.M. Dostojevski, Partizanska knjiga, Beograd;

Milin, L., (2002). Naučno opravdanje religije, Apologetika, Istorija religija, knjiga 2, Grafosrem, Šid;

Marić, D., (1935). Hrišćanstvo i rat, Hrišćanska misao, br. 10. Beograd;

Milaš, N., (2004). Pravila pravoslavne crkve s tumačenjima, knj.2., FineGraf, Beograd;

Popović, J., (2006). Tumačenje Svetog Pisma po Mateju, Manastir Visoki Dečani, Beograd;

Popović, J. (1996). Žitije Sv. Petra cetinjskog, / u: Stanišić, D., (ur.) Boj Crnogoraca i Brđana s Mahmut pašom 1796. SVETIGORA, Cetinje, 1996.

Poznanović, Ž., (2001). Hrišćanstvo i vojska, Vojska i vera, ur. Grozdić, B.,Marković, S., Beograd;

Simeunović, D., (2009). Uvod u političku teoriju, Institut za političke studije, Beograd;

Sinelina, J., (2010). Dinamika religioznosti građana Rusije od 1989 do 2006, U: Teme, TM XXXIV Br. 1, str. 83-96, Niš: 2010; http://teme2.junis.ni.ac.rs/public/journals/1/previousissues/teme1-2010/teme\%201-2010-05.pdf Spinka, M., (1950). Nicolas Berdyaev: Captive of Freedom, Westminster Press, Philadelphia.

Tadić, Lj., (1996). Nauka o politici, Beograd;

Velimirović, N., (1996). Sabrana dela III, Nomologija,Glas Crkve, Valjevo;

Velimirović, N., (1996). Rat i Biblija, Izabrana dela III, Glas Crkve, Valjevo;

Velimirović, N., (2000). Ohridski prolog, Glas Crkve, Šabac;

Dveri Srpske, (2002). Televizijski intervju sa blaženopočivšem Patrijarhom srpskim gospodinom Pavlom koji je vodio Boško Obradović. Razgovor vođen u Manastiru Blagoveštenje (Ovčar Banja) 2002. https://www.youtube.com/ watch?v=5z-XwdDj-wE

\section{PRAVOSLAVNO POIMANJE RATA I NASILJA}

Pitanje uticaja religije, odnosno učenja pojedinih religija na poimanje određenih društvenih, socijalnih i političkih pojava pojedinačno ili u njihovom sadejstvu, od naročitog je značaja naročito kada se ta učenja odnose na pojavne oblike političkog nasilja. Od suštinskog je značaja i pravilan uvid u sličnosti odnosno razlike koje postoje u definisanju autoriteta koji ta tumačenja mogu dati, kao i izvori na koje se pozivaju. U ovom radu autor analizira pravoslavno poimanje pojavnih oblika političkog nasilja, oslanjajući se na dogmatsko učenje Pravoslavne crkve čiji je osnovni izvor Sveto pismo i kanonsko crkveno pravo.

Ključne reči: Pravoslavlje, pojavni oblici političkog nasilja, rat, nasilje, Crkva, Sveto pismo. 